\title{
Research on Influencing Factors of Agricultural Products Logistics in Guangdong Province Based on Grey Correlation Analysis
}

\author{
Fang yan ${ }^{1, a}$ \\ ${ }^{1}$ Heyuan Polytechnic School of Business Administration, Guangdong Heyuan,517000,China \\ a71719330@qq.com
}

\begin{abstract}
Keywords:Guangdong Province;Grey Correlation Analysis;Agricultural Products Logistics; Influencing factors
\end{abstract}

\begin{abstract}
In order to study the influencing factors of agricultural products logistics development in Guangdong Province, Using the relevant statistical data of Guangdong Province from 2010 to 2016, 12 indicators including the value of Gross Output Value of Agriculture, highway freight turnover, etc. were selected to analyze the influence degree of these factors on the development of agricultural products logistics industry in Guangdong province by using grey correlation analysis. The research results show that information transmission, number of computer services and software employees, Internet broadband access users, gross output value of agriculture, highway freight turnover are closely related to agricultural products logistics in Guangdong Province, and the correlation with other factors is general. On this basis, it is proposed to vigorously develop characteristic agriculture, strengthen the construction of agricultural logistics infrastructure, popularize rural Internet access, and encourage "Internet +" agriculture to promote the development of agricultural logistics in Guangdong province.
\end{abstract}

\section{Introduction}

In October 2017, the "Provisional Plan for Promoting Agricultural Supply Side Structural Reform in Guangdong Province” promulgated by Guangdong Province proposed to vigorously develop the processing and circulation industry of agricultural products ${ }^{[1]}$ At present, the agricultural development in Guangdong Province is uneven, the Pearl River Delta economy is developed, but the agricultural industry is weak, and the demand for agricultural products mainly depends on the supply from other places 。As the agricultural production area of Guangdong Province, the mountainous area of Guangdong and North East has a small population. The demand for agricultural products is limited, and a large number of agricultural products need to flow to cities and the Pearl River Delta region and other places. The modernization of agricultural development has also put forward new demands for the development of agricultural products logistics.

\section{Establishment of grey relational analysis model}

The theory of grey relational analysis was proposed and created by Professor Deng Julong in the 1980s. It is specifically aimed at small data samples, especially the small information of uncertain data response. The factors affecting the agricultural product logistics system have obvious timeliness. The recent data has small sample and incomplete information, and has typical gray characteristics. Therefore, it is very suitable to study the factors affecting regional agricultural product logistics development by using grey correlation method. The process of establishing the grey relational model is as follows:

(1) Determine the analysis sequence. Set the reference sequence (also known as the sequence of dependent variables) as $x_{0}=\left\{x_{0}(k) \mid k=1,2, \cdots, \mathrm{n}\right\}$; Comparison series (also called sequence of independent variables $) x_{i}=\left\{x_{i}(k) \mid k=1,2, \cdots, \mathrm{m}\right\}$.

(2) Dimensionless processing of variables. Because the dimensions of each data index are different, the order of magnitude difference may be large, it is not convenient to compare and affect 
the accuracy of comparison. Therefore, in the gray correlation analysis, the data needs to be dimensionless first. The initial value method is used in this paper, The formula is as follows:

$$
\begin{aligned}
& x_{i}(k)=\frac{X_{i}(k)}{X_{i}(1)} ; y_{i}(k)=\frac{Y_{i}(k)}{Y_{i}(1)} \\
& (i=1,2,3 \cdots, m ; k=1,2,3 \cdots, n)
\end{aligned}
$$

(3) Find the absolute difference sequence $\Delta_{0 i}(k)$.The reference sequence $\Delta_{0 i}(k)$ and the comparison sequence ${ }^{x_{i}^{\prime}(k)}$ form an absolute difference sequence $\Delta_{0 i}(k)$ in the absolute value ${ }^{k}$ of the spread, where in $\Delta_{0 i}(k)=\left|x_{0}^{\prime}(k)-x_{i}^{\prime}(k)\right|, \Delta_{i}=\left(\Delta_{01}(k), \Delta_{02}(k), \cdots \Delta_{0 m}(k)\right)$.

(4) Find the maximum difference between the two poles $M$ and the minimum difference $m$.

$$
\mathrm{M}=\max _{i} \max _{k} \Delta_{0 i}(k), m=\min _{i} \min _{k} \Delta_{0 i}(k)
$$

(5)Calculation of the grey correlation coefficient ${ }^{\gamma_{0 i}}$ t. Its calculation formula is as follows:

$$
\gamma_{0 i}=(m+\rho M) /\left[\Delta_{0 i}(k)+\rho M\right], \rho \in(0,1)
$$

Where $k=1,2 \cdots, n ; i=1,2, \cdots, m$. $\rho$ is called the resolution coefficient, and the value interval of $\rho$ is generally $(0,1)$. The specific value may be determined according to the situation, and usually $\rho=0.5$

(6) Calculating grey relational $r_{0 i}=\frac{1}{n} \sum_{k=1}^{n} r_{0 i}(k), i=1,2, \cdots, m$ grade $r_{0 i}$.

\section{Empirical Analysis on the Influencing Factors of Agricultural Products Logistics Development in Guangdong Province}

\subsection{Selection of research variables}

\subsubsection{Selection of dependent variables}

In the literature researching the development of agricultural product logistics, the current development of agricultural product logistics is mainly measured by the volume of freight, the ownership of rural transportation vehicles, transportation, and warehousing and total postal output value. According to the availability of data, in order to find the most suitable dependent variable to represent the development of agricultural logistics industry in Guangdong Province, Selecting the gross output value of the agriculture $\left({ }^{y}\right)$, gross production value of transportation, storage and postal services industry $\left({ }^{r_{1}}\right)$, Freight Ton-kilometers $\left({ }^{r_{2}}\right)$, freight volume $\left({ }^{r_{3}}\right)$ in Guangdong Province from 2010 to 2016,for gray correlation analysis.

It is calculated by using the grey correlation model, the result is $r_{1}=0.9294>r_{3}=0.8734>r_{2}=0.6572$, which shows that the correlation between the logistics output value of Guangdong Province and the total output value of agriculture, forestry, fishery and animal husbandry services is relatively large. Therefore, the logistics output value $\left(r_{2}\right)$ is selected as the dependent variable.

3.1.2 Selection of independent variables.

The independent variable indicator adopts the principle of comprehensiveness, scientificity, representativeness and availability, Combining the actual situation of Guangdong Province, Selecting Gross Output Value of Agriculture $\left(x_{1}\right)$ 、Grain Crops $\left({ }_{2}^{x_{2}}\right)$ 、Major Economic Crops $\left({ }_{3}\right)$ 、 Vegetables $\left({ }^{X_{4}}\right)$ 、 Highways Freight Ton-kilometers $\left({ }^{x_{5}}\right)$ 、Length of Highways $\left({ }^{x_{6}}\right)$ 、Fixed investment 
in Farming, Forestry, Animal Husbandry and Fishery $\left({ }^{x_{7}}\right)$ 、Local fiscal expenditure $\left({ }^{x_{8}}\right)$ 、Number of people employed in transportation, storage and postal services( $\left.{ }^{X_{9}}\right)$ 、Information transmission, computer services and software practitioners $\left({ }^{X_{10}}\right)$, Broadband Subscribers of Internet $\left(X_{11}\right)$ 、 Freight Vehicle $\left(X_{12}\right)$ as independent variables to study the relationship with agricultural products logistics. All data are from the Guangdong Statistical Yearbook (2011-2017). The raw data are shown in Table 1 .

Table 1 Raw material logistics development level and various influencing factors of Guangdong Province

\begin{tabular}{|c|c|c|c|c|c|c|c|}
\hline $\begin{array}{l}\text { index } \\
\text { year }\end{array}$ & 2010 & 2011 & 2012 & 2013 & 2014 & 2015 & 2016 \\
\hline$r_{1_{\text {(100 million yuan) }}}$ & 1793.66 & 2036.25 & 2286.11 & 2450.51 & 2740.76 & 2928.90 & 3208.35 \\
\hline$X_{1}(100$ million yuan $)$ & 3754.86 & 4384.44 & 4656.85 & 4946.81 & 5234.21 & 5520.03 & 6078.43 \\
\hline$X_{2}(10000$ tons $)$ & 1316.50 & 1360.95 & 1396.33 & 1315.90 & 1357.34 & 1358.13 & 1360.22 \\
\hline$X_{3}$ (10000 tons) & 1226.98 & 1299.17 & 1380.63 & 1464.32 & 1418.73 & 1365.54 & 1389.14 \\
\hline$X_{4}(10000$ tons $)$ & 2718.59 & 2850.99 & 2982.71 & 3144.47 & 3274.75 & 3438.78 & 3569.12 \\
\hline$X_{5}$ (100 million ton-km) & 1753.40 & 2150.04 & 2434.95 & 2668.03 & 3113.84 & 3108.81 & 3381.92 \\
\hline$X_{6}(\mathrm{~km})$ & 190144.00 & 190724.00 & 194943.49 & 202914.80 & 212093.76 & 216023.00 & 218084.51 \\
\hline$X_{7}$ (100 million yuan) & 181.83 & 274.28 & 213.58 & 354.24 & 340.05 & 501.09 & 518.70 \\
\hline$X_{8}$ (100 million yuan) & 5421.54 & 6712.40 & 7387.86 & 8411.00 & 9152.64 & 12827.80 & 13446.09 \\
\hline$X_{9}(10000$ persons $)$ & 160.53 & 162.38 & 160.58 & 173.06 & 181.71 & 184.87 & 186.80 \\
\hline$X_{10}(10000$ persons $)$ & 53.94 & 58.06 & 62.08 & 77.89 & 81.17 & 86.62 & 94.96 \\
\hline$X_{11 \text { (10000 subscribers) }}$ & 1523.22 & 1716.30 & 1975.39 & 2154.28 & 2243.87 & 2285.19 & 2850.60 \\
\hline$X_{12 \text { (10000 units) }}$ & 147.53 & 159.92 & 169.86 & 178.89 & 181.81 & 174.90 & 183.02 \\
\hline
\end{tabular}

\subsection{Analysis of Factors Affecting Agricultural Products Logistics in Guangdong Province}

The above data are initialized according to the gray correlation analysis method, and then the correlation between each factor and the agricultural product logistics demand in Guangdong Province is shown in Table 2:

Table 2 Gray correlation degree of agricultural product logistics influencing factors in Guangdong Province

\begin{tabular}{|l|c|c|c|c|c|c|c|c|c|}
\hline index & $\rho_{01}$ & $\rho_{02}$ & $\rho_{03}$ & $\rho_{04}$ & $\rho_{05}$ & $\rho_{06}$ & $\rho_{07}$ & $\rho_{08}$ & $\rho_{09}$ \\
\hline Correlation & 0.8797 & 0.6594 & 0.7167 & 0.7335 & 08242 & 0.6754 & 0.6058 & 0.7316 & 0.6786 \\
\hline index & $\rho_{10}$ & $\rho_{11}$ & $\rho_{12}$ & & & & & & \\
\hline Correlation & 0.9242 & 0.9228 & 0.7484 & & & & & & \\
\hline
\end{tabular}

According to table 3 , the influencing factors of agricultural product logistics development in guangdong province, the grey correlation degree is arranged in order from large to small: $\rho_{10}>\rho_{11}>\rho_{01}>\rho_{05}>\rho_{12}>\rho_{04}>\rho_{08}>\rho_{03}>\rho_{09}>\rho_{06}>\rho_{02}>\rho_{07}$.

Therefore, the factors affecting the development of agricultural products logistics in Guangdong Province are information transmission, computer services and software practitioners, Broadband Subscribers of Internet, Gross Output Value of Agriculture, Highways Freight Ton-kilometers, Freight Vehicles, Vegetables, Local fiscal expenditure, Major Economic Crops, Number of people employed in transportation, storage and postal services, Length of Highways, Grain Crops, Fixed investment in Farming, Forestry, Animal Husbandry and Fishery. Gray correlation results can be found: 
(1)Information, computer services, software employees and Internet broadband access users that have the greatest impact on agricultural products logistics in Guangdong Province, These two indicators represent the reserve of information talents and the development of rural e-commerce. These two indicators have the greatest impact on agricultural product logistics, indicating that with the continuous deepening of the "Internet + " of agricultural products, rural e-commerce is booming, and the sales of agricultural products through various e-commerce channels are increasing, and the development of agricultural e-commerce Promote the speed of circulation of agricultural products and increase the scale of circulation, and more agricultural products go out of the countryside. The access of Internet broadband enables the demand and supply information in rural and urban to be shared, which has become an important factor influencing the development of agricultural product logistics.

(2)The correlation between the total output value of agriculture, forestry, fishery and animal husbandry services and the logistics of farmer products ranks third. This is because the development of agricultural product logistics is closely related to the development of agriculture itself. Only when agriculture develops rapidly can more agricultural products need to be circulated, so as to increase the demand for agricultural products logistics more effectively.

(3)The Highways Freight Ton-kilometers and Freight Vehicle ranked third and fourth for the development of agricultural products logistics in Guangdong Province. These two factors are the basis for the development of agricultural products logistics. Due to the relatively backward rural economy in Guangdong Province, the current circulation of agricultural products mainly depends on road transportation. Therefore, the efficiency of Highways Freight Ton-kilometers and Freight Vehicle have become the key to affect the agricultural products logistics.

(4)The three factors of vegetable production, Local fiscal expenditure , and Major Economic Crops are all above 0.7 for agricultural product logistics in Guangdong Province. At present, Guangdong Province is vigorously developing the cultivation of economic crops under the background of rural revitalization and precise poverty alleviation. The industries in the Pearl River Delta region are quite developed and densely populated, but agricultural production is small. A large amount of vegetable demand and other agricultural product demand are from the supply of eastern, western and Northern Guangdong. Therefore, these three factors have a significant impact on the logistics of agricultural products. It is of great significance to build a vegetable circulation information network platform, improve the agricultural product wholesale market system, and vigorously develop deep processing of agricultural products, to promote rural economic development and industrial structure upgrading, and increase farmers' income.

(5)The relationship between Number of people employed in transportation, storage and postal services, Length of Highways, Grain Crops, Fixed investment in Farming, Forestry, Animal Husbandry and Fishery and agricultural product logistics in Guangdong Province is low. This is because on the one hand, these four factors have little effect on the promotion of agricultural products logistics in Guangdong Province, and there is room for improvement. On the other hand, it also shows that the current development of infrastructure and agricultural industry plays a very important role in the agricultural logistics of Guangdong Province. Therefore, it is necessary to strengthen the development of infrastructure and agricultural industries in order to better promote the development of agricultural products logistics in Guangdong Province.

\section{Countermeasures and suggestions for promoting the development of agricultural products logistics in Guangdong}

At present, the development of agricultural product logistics in Guangdong Province is not developed enough.As an important province of coastal economic development in China, although industrial economic development has made remarkable achievements, the agricultural resources in east-west and North Guangdong are very rich and of good quality, but the rural economy has been in a relatively backward state.This requires vigorous development of agricultural product logistics to drive the development of regional rural economy. 
(1) According to the actual situation in different parts of the country, we should give prominence to the development of characteristic superior agriculture and increase the supply of green and high-quality agricultural products in a planned way. Guangdong Province is rich in natural resources in the mountainous areas of eastern and Western Guangdong and the coastal areas. A large number of agricultural products, such as tropical fruits, vegetables, Chinese herbs, poultry and special seafood, are well known throughout the country and the world. The development potential of special agricultural products is great. First of all, according to the local conditions, each region should select the varieties of agricultural products to be adapted to local conditions , and increase the capital and technology investment to build a large-scale, intensive and high-quality raw material production base for characteristic agricultural products; Secondly, we will support the construction of a number of agricultural finishing enterprises that integrate production, processing and sales, and have independent brands and innovative capabilities. Thirdly, local governments need to actively introduce advanced technology to solve the difficulties encountered in the development process of agricultural enterprises, vigorously support the development and innovation of agricultural products, assist agricultural production and processing enterprises to create famous brands, and take the road of brand innovation. The characteristic agricultural products of Guangdong will be changed from the current extensive and extensive type to intensive type.

(2) Improving rural logistics infrastructure construction and increasing cooperation between logistics enterprises and agricultural enterprises. On the one hand, the government needs to strengthen the construction of logistics infrastructure such as rural roads, cold storage, cold chain transportation, and agricultural product wholesale distribution centers. To ensure that villages and villages pass through highways, and large trucks and container trucks can reach all agricultural production sites and solve the problem of transportation difficulties;

Agricultural products logistics enterprises are encouraged to build refrigerated storage and introduce advanced refrigeration technology; subsidize the construction of refrigerated storage and electricity consumption; to purchase refrigerated transport vehicles and subsidize the purchase of refrigerated transport vehicles, so as to increase their enthusiasm for investment and increase the supply of cold chains. It is necessary to increase the construction of the wholesale market of agricultural products. The main production base of agricultural products should have a wholesale market to ensure timely trading of agricultural products. Secondly, we should support the development of leading agricultural products logistics enterprises, encourage logistics enterprises to strengthen cooperation with agricultural production enterprises, rural cooperatives and other enterprises, to achieve bulk transportation of agricultural products, specialization of agricultural logistics, and reduce logistics costs, Promote the construction of township and village-level agricultural product logistics service stations, and realize the effective docking of logistics service stations and township agricultural products wholesale markets.

(3)We should promote "Internet +" modern agriculture and encourage the development of rural e-commerce. On the one hand, the government should strengthen the construction of the information platform of agricultural products market, release the information of supply and demand of agricultural products and logistics of agricultural products through the information platform of agricultural products market, realize the real-time exchange and sharing of agricultural production circulation data, and promote the effective integration of logistics, business flow and information flow, Strengthen rural e-commerce logistics, cold chain logistics, wisdom and other construction, realize the agricultural products sales for switching from traditional economic model to the electronic commerce mode, using the internet technology integration of all kinds of resources, innovative logistics distribution mode, through the joint distribution and sharing logistics mode method solve the problem of scattered rural logistics demand, improve the efficiency of terminal distribution. On the other hand, it popularizes Internet access in rural areas, strengthens farmers' mobile phone application training skills, and enhances the informationization ability of agricultural employees. The popularity of smart phones and the popularization of rural Internet construction allow farmers to log on to the agricultural product information platform to obtain agricultural product supply and demand 
information and obtain logistics supply without using a computer at home, so as to realize the rapid transmission of agricultural product supply and demand information.

\section{Acknowledgments}

This research was financially supported by the Heyuan City Philosophy and Social Sciences "13th Five-Year Plan" "Key Projects"(Grant No. HYSK17Z05) and Guangdong Provincial Department of Education 2017 Key Platform and Research Projects (Grant No.2017GWTSCX044).

\section{References}

[1] Guangdong Provincial People's Government.Guangdong to promote agricultural supply-side structural reform implementation plan. Guangdong province (2017) No. 118.(2017-10-31) [2018-9-12] http://zwgk.gd.gov.cn/006939748/201711/t20171129_732689.html

[2] Statistics Bureau of Guangdong Province, statistical yearbook (2011-2017).(R/OL). (03-02-2018) [09-12-2018]http://www.Gdstats.gov.cn

[3] Sun Liangtao.Study on Factors Influence Agricultural Produce Logistics in Yunnan Based on Grey Correlation Analys.Logistics Technology.vol(33),PP:208-2011,2014

[4] Logistics Technology.Analysis of the Influencing Factors of Rural Logistics in Anhui Province Based on Improved GRA.Journal of Inner Mongolia University of Finance and Economics.vol(15) PP: 24-27

[5] Liu S,Forrest J,Yang Y.A Brief Introduction to Grey System Theory[J].Grey System:Theory and Application,2012(2)

[6] Liu Sifeng, Xie Naiming. Grey System Theory and Its Application (Sixth Edition)[M]. Beijing: China Statistics Press.2013 